\title{
OPTIMIZATION OF HYDROPHILIC INTERACTION LIQUID CHROMATOGRAPHIC METHOD FOR SIMULTANEOUS DETERMINATION OF CETYLPYRIDINIUM CHLORIDE AND BENZOCAINE IN LOZENGES
}

\author{
Natalija Nakov*, Jelena Acevska, Katerina Brezovska, \\ Rumenka Petkovska, Aneta Dimitrovska \\ Ss. Cyril and Methodius University, Faculty of Pharmacy, \\ Institute of Applied Chemistry and Pharmaceutical Analysis, \\ Vodnjanska 17, 1000 Skopje, Republic of Macedonia \\ natalijan@ff.ukim.edu.mk,n.cukic@yahoo.com
}

\begin{abstract}
A new Hydrophilic Interaction Liquid Chromatography (HILIC) method was developed for simultaneous determination of cetylpyridinium chloride and benzocaine as active substances in lozenges. Method development included investigation of the influence of the critical chromatographic conditions such as: type of organic modifier, mobile phase strength, ionic strength and $\mathrm{pH}$ value of the buffer used in the mobile phase, as well as experimental determination of dominant mechanism of retention. The optimal chromatographic conditions were obtained using bare silica column and a mobile phase consisting of acetonitrile and ammonium formate $(50 \mathrm{mM}, \mathrm{pH}=4.0)$ in ratio $80: 20 \mathrm{~V} / \mathrm{V}$. The method was validated in terms of specificity, linearity, accuracy and precision. The validation results indicate that the proposed HILIC method is suitable for quantitative analysis of cetylpyridinium chloride and benzocaine in lozenges.
\end{abstract}

Keywords: benzocaine; cetylpyridinium chloride; HILIC; lozenges; retention mechanism

\section{ОПТИМИЗАЦИЈА НА ТЕЧЕН ХРОМАТОГРАФСКИ МЕТОД СО ХИДРОФИЛНА ИНТЕРАКЦИЈА ЗА ЕДНОВРЕМЕНО ОПРЕДЕЛУВАҢЕ НА ЦЕТИЛПИРИДИН ХЛОРИД И БЕНЗОКАИН ВО ПАСТИЛИ}

\begin{abstract}
Развиен е нов метод за едновремено определување на цетилпиридин хлорид и бензокаин во пастили со примена на течна хроматографија со хидрофилна интеракција (HILIC). При развојот на методот испитано е влијанието на критичните хроматографски параметри: тип на органскиот елуент, јачина на мобилната фаза, јонска јачина и $\mathrm{pH}$ на пуферот кој влегува во составот на мобилната фаза. Исто така, направено е експериментално испитување на доминантниот механизам на ретенцијата на испитуваните компоненти. Оптимални хроматографски услови се постигнати со примена на необработена силика како стационарна фаза и смеса од ацетонитрил и амониум формат (50 $\mathrm{mM}$, pH 4,0) во однос $80: 20 \mathrm{~V} / \mathrm{V}$ како мобилна фаза. Предложениот метод е валидиран во однос на специфичност, линеарност, точност и прецизност. Резултатите од валидацијата покажаа дека методот е погоден за квантитативна анализа на цетилпиридин хлорид и бензокаин во пастили.
\end{abstract}

Клучни зборови: бензокаин; цетилпиридин хлорид; HILIC; пастили; механизам на ретенција 


\section{INTRODUCTION}

Quaternary ammonium compounds are widely used in lozenges formulations for their antimicrobial activity in treatment of common infections of mouth and throat. Cetylpyridinium chloride (CPC), a cationic surfactant which acts as antibacterial agent, is the most commonly used active substance in these preparations [1]. In addition to the antibacterial agent, lozenges for treatment of mouth infections can contain a local anesthetic, which is usually benzocaine (BC). Benzocaine is an ester-type local anesthetic that reversibly blocks nerve function [2].

In the literature data several methods for determination of cetylpyridinium chloride are proposed, including titration, spectroscopy, capillary electrophoresis and liquid chromatography [3-8]. According to USP 31, assay of cetylpyridinium chloride in cetylpyridinium lozenges is based on volumetric determination, whereas quantitative determination of benzocaine in benzocaine lozenges is based on reverse-phase liquid chromatography [9]. The method for simultaneous determination of cetylpyridinium chloride and benzocaine in tablet described in the literature is based on ion-pair reverse phase chromatography, using dioctyl sulphosuccinate as an ion-pair reagent in complex mobile phase (water-chloroform-methanol) [10]. Retention of the ionic compounds on the reverse phase stationary phase can be improved by adding ion-pair reagent(s) in the mobile phase, but the ion-pair reverse-phase chromatographic methods have number of disadvantages [11-13].

In the recent years, hydrophilic interaction liquid chromatography (HILIC) has been proved to be a useful technique for separation of polar compounds, providing an alternative separation mechanism to traditional reversedphase liquid chromatography. HILIC is a technique, where analyte retention is believed to be caused by partitioning of the analyte between a water-enriched layer of stagnant eluent on a hydrophilic stationary phase and a relatively hydrophobic bulk eluent [11].
The aim of this work was to optimize a HILIC method for simultaneous determination of cetylpyridinium chloride and benzocaine, which can be easily used in routine analysis of pharmaceutical preparations containing combination of these compounds. Considering the multimodal mechanism involved in retention of compounds in HILIC, an effort was made to study the contribution of adsorption, partition and ion-exchange mechanism to the retention of cetylpyridinium chloride and benzocaine on bare silica column.

\section{EXPERIMENTAL}

Instrumentation. All the experiments were performed on Agilent Rapid Resolution HPLC 1200 system equipped with vacuum degasser (G1379B), a binary pump (G1362B), autosampler (G1367C), a column compartment (G1316B), diode array detector (G1315C) and ChemStation for LC 3D software for data handling.

Reference substances, reagents and chemicals. Cetylpyridinium chloride (purity $97.7 \%$ ) and benzocaine (purity $99.3 \%$ ) working standards were obtained from KRKA d.d. Novo Mesto, Slovenia. Ammonium formate (Fluka, Switzerland), ammonium hydroxide solution c.c $25 \% \mathrm{NH}_{3}$ (Sigma-Aldrich, Germany) and formic acid 98-100 \% (Merck, Germany) of analytical grade were used. Acetonitrile (Merck, Germany) and water (TKA-LAB Reinstwasser system) of HPLC grade were used.

Chromatographic conditions. Separation of cetylpyridinium chloride and benzocaine was performed on Purospher STAR Si $150 \cdot 4.6 \mathrm{~mm}, 5$ $\mu \mathrm{m}$ column, under isocratic conditions using mixture of acetonitrile and ammonium formate $(\mathrm{pH}$ $4.0 ; 50 \mathrm{mM}$ ) in ratio $80: 20 \mathrm{~V} / \mathrm{V}$ as mobile phase with flow rate $0.5 \mathrm{ml} / \mathrm{min}$, at $25^{\circ} \mathrm{C}$. The injection volume was $10 \mu \mathrm{l}$. Detection was performed at $254 \mathrm{~nm}$. Mixture of acetonitrile and ammonium formate $(\mathrm{pH} 4.0 ; 50 \mathrm{mM})$ in ratio $90: 10 \mathrm{~V} / \mathrm{V}$ was used as a solvent for all solutions. 
Standard solutions. Standard stock solution of CPC in concentration of $0.4 \mathrm{mg} / \mathrm{ml}$ and standard stock solution of BC in $1.0 \mathrm{mg} /$ $\mathrm{ml}$ were prepared. Standard solution was prepared by mixing the appropriate quantities of each stock solution to obtain concentration of $0.02 \mathrm{mg} / \mathrm{ml}$ for cetylpyridinium chloride and $0.1 \mathrm{mg} / \mathrm{ml}$ for benzocaine.

Six serial dilutions from each stock solution were prepared for the calibration curve in the range of 0.01 to $0.03 \mathrm{mg} / \mathrm{ml}$ for cetylpyridinium chloride and 0.05 to $0.15 \mathrm{mg} / \mathrm{ml}$ for benzocaine (50 to $150 \%$ of the working concentration).

Sample solution. SEPTOLETE® Plus lozenges with honey and lime flavor $(5 \mathrm{mg}$ benzocain and $1 \mathrm{mg}$ cetylpyridinium chloride) were used for preparation of the sample solution. Four lozenges were dissolved in a $200 \mathrm{ml}$ volumetric flask (US bath for $30 \mathrm{~min}$ at $40^{\circ} \mathrm{C}$ ) and diluted with the solvent to volume. The sample solution was centrifuged at $3500 \mathrm{rpm}$ for $10 \mathrm{~min}$ and filtered through $0.45 \mu \mathrm{m}$ membrane filter.

The determination of accuracy of the method was done by method of standard additions, by adding known amounts of cetylpyridinium chloride and benzocaine standard to the sample placebo at three concentrations $(75 \%$, $100 \%$ and $125 \%$ ).

\section{RESULTS AND DISCUSSION}

In HILIC, a hydrophilic stationary phase (most often bare silica) and an aqueous-organic mobile phase with high organic solvent are used [14]. Retention mechanism in HILIC is complex and partition mechanism may occur together with adsorption, ion exchange and even hydrophobic interaction under appropriate experimental conditions [15]. The predominant retention mechanism in HILIC is not persistent and it can be varied from one to another, especially when different analytes, mobile and stationary phases are applied [14-16].
In this work, HILIC method for simultaneous determination of cetylpyridinium chloride and benzocaine was optimized. In order to obtain optimal chromatographic conditions for separation of the two components, the influence of the critical chromatographic conditions: types of organic modifier, mobile phase strength, ionic strength and $\mathrm{pH}$ value of the buffer used in the mobile phase were optimized. Also, the predominant mechanism of retention of the compounds was investigated.

\subsection{Influence \\ of the type of the organic modifier}

The organic eluents that are used in HILIC can be subdivided into polar protic (methanol, ethanol and isopropanol) and polar aprotic (acetonitrile and tetrahydrofuran). The protic solvents are stronger solvents in HILIC, because they compete with the analyte for the active polar stationary phase sites, resulting in shortening the retention time of the analyte [15]. The influence of two protic (methanol and ethanol) and one aprotic (acetonitrile) solvent on the retention of the cetylpyridinium chloride and benzocaine was investigated. Mobile phase containing each of the organic modifiers and ammonium formate $(20 \mathrm{mM}, \mathrm{pH} 4.0)$ in ratio $80: 20 \mathrm{~V} / \mathrm{V}$ was used for this experiments (Figure 1).

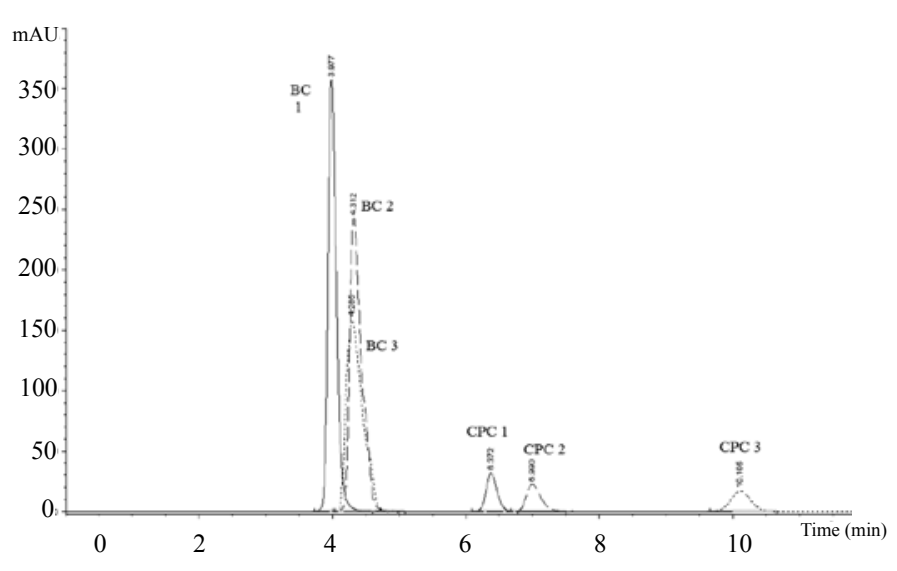

Fig. 1. Influence of the type of the organic modifier ( 1 - acetonitrile, 2 - methanol, 3 - ethanol) 
The type of organic modifier has shown influence on the retention on cetylpyridinium chloride peak, but not as it was expected according to the solvent strength series. Methanol and ethanol provided longer retention time on cetylpyridinium chloride compared to acetonitrile. This indicates that the retention behavior of the compounds in HILIC cannot be predicted only by the strength of the solvent used in the mobile phase. These properties depend of the nature of the analyte and the stationary phase used. For this reason the influence of the organic modifier should be practically investigated for each compound. On the other hand, the type of organic modifier had no influence on retention of benzocaine, but it was found that the protic solvents used in this experiment caused broadening of the benzocaine peak. This peak broadening may be caused by the possible extra resonance structures produced by the hydrogen-bonding interaction between the protic solvents and the benzocaine molecules. When acetonitrile was used in the mobile phase no peak broadening was observed, because it is an aprotic solvent and does not give hydrogen-bonding interaction. Acetonitrile was chosen as an organic modifier in the mobile phase, because it provided shorter retention times compared to protic solvents and symmetrical peaks for both of the compounds.

\subsection{Influence of the mobile phase strength}

In HILIC, the mobile phase usually contains at least $3 \%$ of water phase, which represent the stronger eluent [14]. In this study the influence of the percentage of the water phase (ammonium formate $20 \mathrm{mM}, \mathrm{pH} 4.0$ ) was investigated in the range from $10-23 \%$. Increasing the percentage of the ammonium formate $20 \mathrm{mM}, \mathrm{pH} 4.0$ in the mobile phase reduced the retention of cetylpyridinium chloride and had no influence on the retention of benzocaine (Figure 2). Mixture of acetonitrile and ammonium formate $20 \mathrm{mM}, \mathrm{pH} 4.0$ in ratio $80: 20 \mathrm{~V} / \mathrm{V}$ was chosen as an optimal mobile phase for separation of the two components.

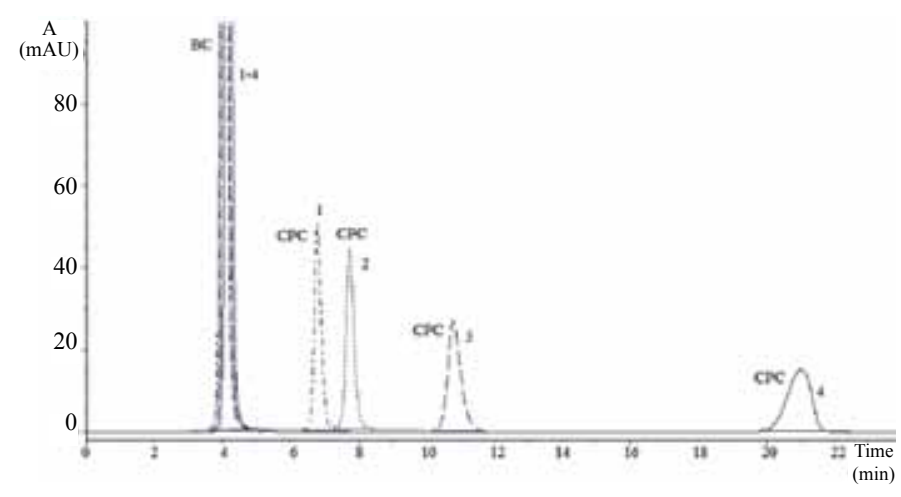

Fig. 2. Influence of the mobile phase strength: 1) $23 \%$ ammonium formate $20 \mathrm{mM}, \mathrm{pH} 4.0,2) 20 \%$ buffer, 3) $15 \%$ buffer,

4) $10 \%$ buffer, each contained acetonitrile up to $100 \%$ (explicitly provide the composition of the buffer)

To study whether adsorption or partition is the dominant retention mechanism of cetylpyridinium chloride and benzocaine, the relationship between the retention factor $\left(k^{\prime}\right)$ and the water phase (volume fraction and mole fraction) was analyzed [10, 16, 17]. For that purpose adsorption plot (log $k^{\prime}$ vs. $\log$ mole fraction of water phase) and partition plot (log $k^{\prime}$ vs. volume frac-

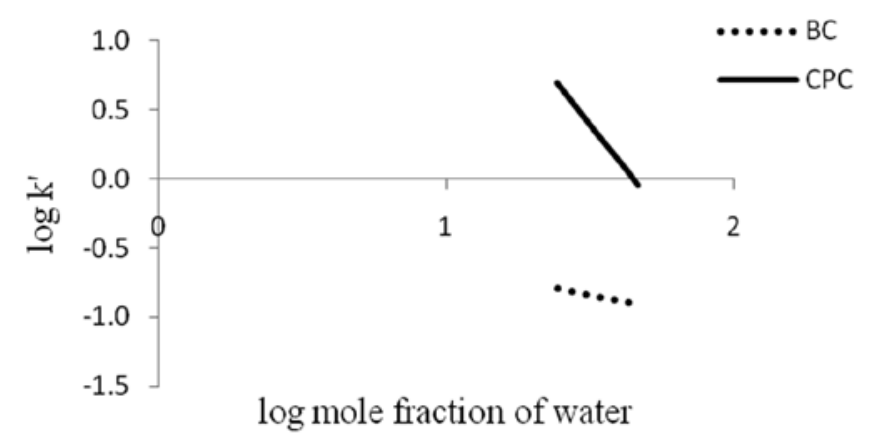

a)

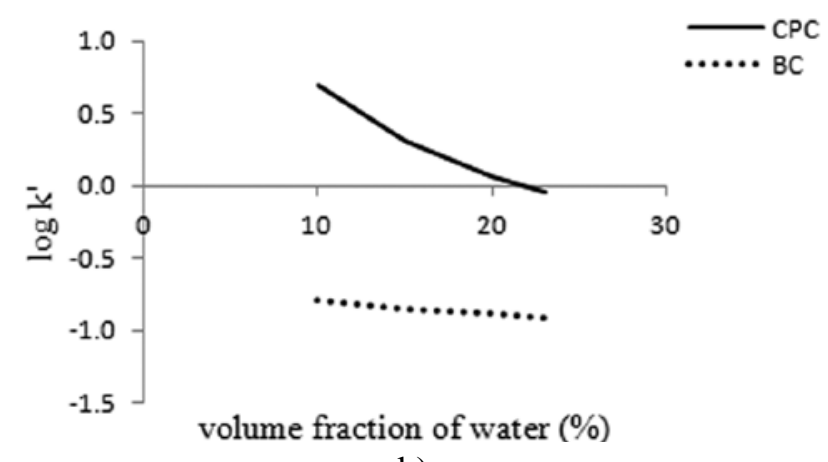

b)

Fig. 3. a) Adsorption plot b) Partitionplot 
tion of water phase) were compared (Figures $3 \mathrm{a}$ and $3 \mathrm{~b}$ ). The correlation coefficient of cetylpyridinium chloride obtained from the adsorption plot was higher than the correlation coefficient of cetylpyridinium chloride obtained for partition plot (Table 1), pointing the higher linearity of the adsorption plot, which indicates that the adsorption mechanism of retention is dominant. On the other hand, the obtained values for correlation coefficients from the adsorption and partition plot for benzocaine were very similar (Table 1), so it could not be concluded whether adsorption or partition dominated as mechanism of retention for benzocaine.

\section{Table 1}

Values for the intercept (a), slope (b) and correlation coefficient $\left(R^{2}\right)$ obtained from the adsorption and partition plot

\begin{tabular}{ccccc}
\hline \hline & \multicolumn{2}{c}{ Adsorption plot } & \multicolumn{2}{c}{ Partition plot } \\
\hline & CPC & BC & CPC & BC \\
\hline $\mathrm{a}$ & 4.3304 & 0.2045 & 1.2119 & 0.7023 \\
$\mathrm{~b}$ & -2.6262 & -0.4251 & -0.0563 & -0.0092 \\
$\mathrm{R}^{2}$ & 0.9999 & 0.9830 & 0.9780 & 0.9864 \\
\hline \hline
\end{tabular}

\subsection{Influence of the $p H$ of buffer}

The effect of $\mathrm{pH}$ value of the water phase was investigated by using different $\mathrm{pH}$ values $(2.5,4.0,5.0$ and 7.0$)$ of the ammonium formate buffer $(20 \mathrm{mM})$ in the mobile phase. By increasing the $\mathrm{pH}$ value of the water phase, the retention time of cetylpyridinium chloride increased, but the retention of benzocaine was reduced. The surface silanol groups on the bare silica stationary phase $(\mathrm{pKa} \sim 4)[18]$ are negatively charged at $\mathrm{pH}$ 7.0. Cetylpyridinium chloride as a quaternary ammonium salt $[1]$ is positively charged at $\mathrm{pH}$ values bellow 7.0. The increased retention of cetylpyridinium chloride at $\mathrm{pH} 7.0$ may be explained by the electrostatic interaction between the anionic silanol groups and the cationic groups of cetylpyridinium chloride. The retention of benzocaine
( $\mathrm{pKa} 2.5$ ) [19] at higher $\mathrm{pH}$ values of the buffer, was reduced due to the electrostatic repulsion from the anionic surface silanol groups. The $\mathrm{pH}$ 4.0 was chosen as optimum because it provided optimal retention for both benzocaine and cetylpyridinium chloride.

\subsection{Influence of the ionic strength of the buffer used in the mobile phase}

The ionic strength of the buffer used in the mobile phase has a significant effect on the retention of polar compounds in HILIC, due to its influence on the degree of ionization of the analyte and the stationary phase and the polarity of the mobile phase $[16,20]$. The effect of ionic strength on retention time was investigated using different concentrations ( $10 \mathrm{mM}, 20 \mathrm{mM}, 50 \mathrm{mM}$, $70 \mathrm{mM}$ and $90 \mathrm{mM}$ ) of ammonium formatein buffer ( $\mathrm{pH}$ 4.0) used in the mobile phase. By increasing the concentration of ammonium formate, the retention time of cetylpyridinium chloride has reduced, due to the increased eluting strength of the mobile phase, by higher salt concentration (Figure 4). Furthermore, increased concentration of counter ion (ammonium ion) in the buffer reduces the electrostatic interaction between the analyte and the surface silanol groups on silica column by competing with the analyte for these sites, resulting in reduced retention time. The ionic strength of the mobile phase had no effect on the retention of benzocaine (Figure 4). The optimal separation of the two components was obtained using 50 $\mathrm{mM}$ ammonium formate.

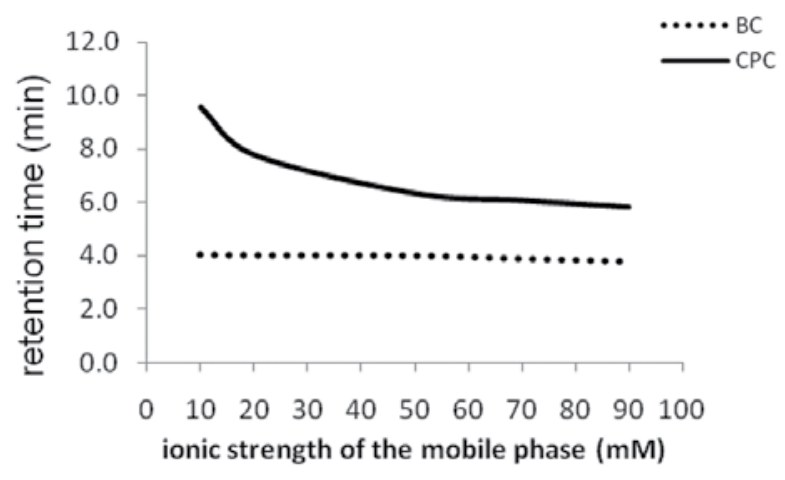

Fig. 4. Plot retention time vs. ionic strength of the mobile phase (mM) 
T a b 1 e 2

\section{Contribution of ion exchange (\%) to retention of compounds}

\begin{tabular}{ccc}
\hline \hline & \multicolumn{2}{c}{ Contribution of ion exchange (\%) } \\
\cline { 2 - 3 }$\left[\mathrm{M}^{+}\right](\mathrm{mM})$ & Cetylpyridinium & Benzocaine \\
\hline 10 & 68 & 12 \\
20 & 54 & 12 \\
50 & 32 & 4 \\
70 & 23 & 4 \\
90 & 14 & 0 \\
\hline \hline
\end{tabular}

The obtained values for $k^{\prime}$ of cetylpyridinium chloride and benzocaine were used for experimental estimation of the contribution of the ionic component of the buffer on retention of the compounds. For that purpose, data obtained from regression analysis of the plot $k^{\prime}$ vs. reciprocal values of concentration of ammonium formate in the buffer $(1 /[\mathrm{M}+])$ were used for calculation of the percent contribution of the ion exchange to retention of the compounds [15, 21, 22]. The obtained results for the contribution of ion exchange to the retention mechanism of the compounds are presented in Table 2. The percent contribution of the ion exchange is found to be bigger at lower counter-ion concentration for both of the components. At $10 \mathrm{mM}$ counter-ion concentration, $68 \%$ of the retention of cetylpyridinium chloride and $12 \%$ of the retention of benzocaine was due to the ionic processes. At $90 \mathrm{mM}$ concentration the ionic contribution was found to be $14 \%$ for cetylpyridinium chloride and $0 \%$ for benzocaine. From these results it is obvious that the contribution of ion exchange mechanism to retention was greater on cetylpyridinium chloride than on benzocaine, corresponding to the finding that the ionic strength of the buffer used in the mobile phase had significant influence on the retention of cetylpyridinium chloride and no influence on the retention of benzocaine.

The optimal chromatographic conditions were obtained using mobile phase composition of acetonitrile and ammonium formate $(\mathrm{pH} 4.0 ; 50$ $\mathrm{mM}$ ) in ratio $80: 20 \mathrm{~V} / \mathrm{V}$ (Figure 5). Results from system suitability are given in Table 3 .

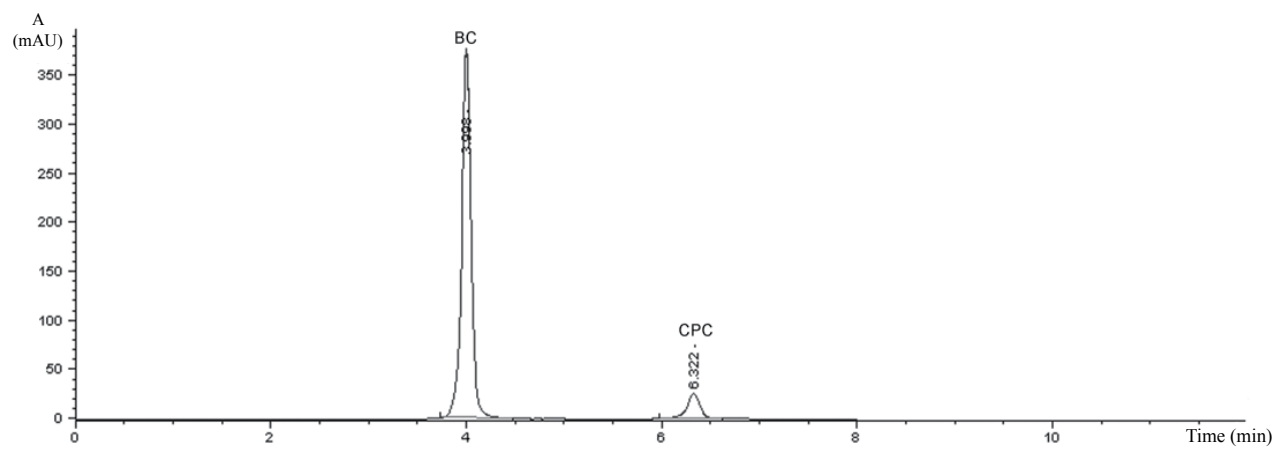

Fig. 5. Chromatogram of the sample solution

Table 3

Results obtained from system suitability testing

\begin{tabular}{ccc}
\hline \hline Parameter & Benzocaine & $\begin{array}{c}\text { Cetylpyridinium } \\
\text { chloride }\end{array}$ \\
\hline$k^{\prime}$ & 1.2 & 2.6 \\
As & 0.93 & 1.13 \\
$\mathrm{~N}$ & 9621 & 12546 \\
$\mathrm{Rs}$ & & 11.9 \\
Peak area $(n=6)$, & 2533.47 & 239.25 \\
$\mathrm{RSD} \%$ & 0.17 & 0.07 \\
$\mathrm{RT}(n=6)$, & 3.99 & 6.32 \\
$\mathrm{RSD} \%$ & 0.01 & 0.05 \\
\hline \hline
\end{tabular}

\subsection{Validation of the method}

The validation of the method included determination of the specificity, linearity, accuracy, repeatability and intermediate precision, according to the ICH [23]. In the chromatograms obtained after injection of solvent, placebo, standard solution and sample solution, there were no interfering peaks with cetylpyridinium chloride and benzocaine peak. The validation results indicate that the method is specific, linear, accurate and precise (Table 4 and Table 5). 
$\mathrm{T} \mathrm{a} \mathrm{b} 1$ e 4

Validation parameters of the developed HILIC method

\begin{tabular}{lcc}
\hline \hline Validation parameter & Cetylpyridinium chloride & Benzocaine \\
\hline Linearity & & \\
Concetration range $(\mathrm{mg} / \mathrm{ml})$ & $0.01-0.03$ & $0.05-0.15$ \\
Correlation coefficient & 0.9993 & 0.9996 \\
Intercept & 0.2705 & 11.665 \\
Slope & 12252 & 25266 \\
\hline Precision (RSD \%) & & \\
Repeatability & & \\
$100 \%(n=6)$ & 0.14 & 0.06 \\
Intermediate precision $(n=6)$ & & \\
Analyst 1 & 0.06 & 0.17 \\
Analyst 2 & 0.22 & 0.08 \\
\hline \hline
\end{tabular}

T a b l e 5

Accuracy of the developed HILIC method

\begin{tabular}{lccccc}
\hline \hline & $\begin{array}{c}\text { Working } \\
\text { concentration } \\
(\mu \mathrm{g} / \mathrm{ml})\end{array}$ & $\begin{array}{c}\text { Added } \\
(\mu \mathrm{g} / \mathrm{ml})\end{array}$ & $\begin{array}{c}\text { Determinated } \\
(\mu \mathrm{g} / \mathrm{ml})\end{array}$ & $\begin{array}{c}\text { RSD } \\
(\%)\end{array}$ & $\begin{array}{c}\text { Recovery }(\%) \\
\mathrm{P}=95 \%\end{array}$ \\
\hline & 15 & 16.5 & 16.2 & 0.25 & $98.47 \pm 0.60$ \\
Cetylpyridinium & 20 & 20.5 & 20.4 & 0.11 & $99.29 \pm 0.28$ \\
chloride & 25 & 27.5 & 27.1 & 0.15 & $98.40 \pm 0.36$ \\
& 75 & 77.0 & 76.5 & 0.08 & $99.30 \pm 0.20$ \\
Benzocaine & 100 & 104.0 & 104.0 & 0.06 & $100.04 \pm 0.15$ \\
& 125 & 110.0 & 109.0 & 0.06 & $99.02 \pm 0.15$ \\
\hline \hline
\end{tabular}

\section{CONCLUSION}

A simple and rapid method based on Hydrophilic Interaction Liquid Chromatography was optimized for simultaneous determination of cetylpyridinium chloride and benzocaine in lozenges. The results obtained from the investigation of the retention mechanism had shown that adsorption mechanism is dominat for cetylpyridinium chloride. On the other hand, for benzocaine due to its low retention, the mechanism of retention could not be established. The contribution of the ion exchange mechanism to retention was greater on cetylpyridinium chloride than on benzocaine and it depended of the ionic strength of the buffer used in the mobile phase. Validation results have shown that the method is selective, linear, accurate and precise, and it is suitable for quantitative analysis of cetylpyridinium chloride and benzocaine in lozenges. 


\section{REFERENCES}

[1] R. B. Taylor, S. Toasaksiri, R. G. Reid, D. Wood, Determination of the quaternary ammonium compounds dequalinium and cetylpyridinium chlorides in candy-based lozenges by high-performance liquid chromatography, Analyst. 122, 973-976 (1997).

[2] Martindale the extra pharmacopoeia, Royal Pharmaceutical Society of Great Britain, London, England, 1996.

[3] European Pharmacopeia 7.0, Council of Europe, Strasbourg, France, 2010.

[4] M. Benamor, N. Aguersif, M.T. Draa, Spectrophotometric determination of cetylpyridinium chloride in pharmaceutical products, J. Pharm. Biomed. Anal. 26, 151-154 (2001).

[5] L. J. Schep, D. S. Jones, I. Tucher, M. G. Shepherd, A colorimetric ion-pairing analytical method for quaternay ammonium compounds using eosin$\mathrm{Y}$ and Triton X-100, Int. J. Pharm. 113, 263-266 (1995).

[6] R. B. Taylor, S. Toasaksiri, R. G. Reid, Determination of antibacterial quaternary ammonium compounds in lozenges by capillary electrophoresis, $J$. Chromatogr. A 798, 335-343 (1998).

[7] L. M. Nair, R. Saari-Nordhaus, Recent developments in surfactant analysis by ion chromatography, J. Chromatogr. A 804, 233-239 (1998).

[8] J. Wang, J. Lu, L. Zhang, Y. Hu, Determination of cetylpyridinium chloride and tetracaine hydrochloride in buccal tablets by RP-HPLC, J. Pharm. Biomed. Anal. 32, 381-386 (2003).

[9] United States Pharmacopeia 31, United States Pharmacopeial Convention, Washington, 2008.

[10] P. Linares, M. C. Gutierrez, F. Lazaro, M. D. Luque de Castro, M. Valcarcel, Determination of benzocaine, dextromethorphan and cetylpyridinium ion by high-performance liquid chromatography with UV-detection, J. Chromatogr. A 558, 147-153 (1991).

[11] P. Hemström, K. Irgum, Hydrophilic interaction chromatography, J. Sep. Sci. 29, 1784-1821 (2006).

[12] B. Dejaegher, Y. Vander Heyden, HILIC methods in pharmaceutical analysis, J. Sep. Sci. 33, 698-715 (2010).
[13] L. Snyder, J. Kirkland, J. Dolan, Introduction to modern liquid chromatography, third ed., John Wiley \& Sons Inc. : Hoboken, New Jersey, USA, 2010.

[14] B. Dejaegher, D. Mangelings, Y. Vander Heyden, Method development for HILIC assays, J. Sep. Sci. 31, 1438-1448 (2008).

[15] Z. Hao, B. Xiao, N. Weng, Impact of column temperature and mobile phase components on selectivity of HILIC, J. Sep. Sci. 31, 1449-1464 (2008).

[16] D. V. McCalley, Study of selectivity, retention mechanism and performances of alternative silica based stationary phases for separation of ionised solutes in hydrophilic interaction chromatography, J. Chromatogr. A 1217, 3408-3417 (2010).

[17] A. E. Karatapanis, Y. C. Fiamegos, C.D. Stalikas, Study of the behavior of water- soluble vitamins in HILIC on a diol column, Chromatographia 71, 751-759 (2010).

[18] A. E. Karatapanis, Y. C. Fiamegos, C.D. Stalikas, A revise to the retention mechanism of hydrophilic interaction liquid chromatography using model organic compounds, J. Chromatogr.A 1218, (2011) 2871-2879.

[19] A. C. Moffat, M. D. Osselton, B. Widdop Eds., Clarke's Isolation and Identification of Drugs. The Pharmaceutical Society of Great Britain, London, England 1986.

[20] Y. Guo, S. Gaiki, Retention behavior of small polar compounds on polar stationary phases in hydrophilic interaction chromatography, J. Chromatogr. A 1074, 71-80 (2005).

[21] G. B. Cox, R. W. Stout, Study of the retention mechanism for basic compound on silica under pseudo-reversed conditions, J. Chromatogr. 384, 315-336 (1987).

[22] X. Yang, J. Dai, P. W. Carr, Analysis and critical comparison of the reversed-phase and Ion-exchange contribution to retention on polybutadiene coated zirconia and octadecyl silane bonded silica phases, J. Chromatogr. A 996, 13-31(2003).

[23] International Conference on Harmonization Techical Requirements for Registration of Pharmaceuticals for Human Use Guideline on Validation of Analytical Procedures: Text and Methodology Q2(RI), Geneva, Switzerland (2005). 